\title{
Removal of Ammonium Ions from Aqueous Solutions Using Weathered Halloysite
}

\author{
Jacek Leszczyński
}

check for

updates

Citation: Leszczyński, J. Removal of Ammonium Ions from Aqueous

Solutions Using Weathered

Halloysite. Materials 2021, 14, 4359.

https://doi.org/10.3390/ma14164359

Received: 2 July 2021

Accepted: 2 August 2021

Published: 4 August 2021

Publisher's Note: MDPI stays neutral with regard to jurisdictional claims in published maps and institutional affiliations.

Copyright: (C) 2021 by the author. Licensee MDPI, Basel, Switzerland. This article is an open access article distributed under the terms and conditions of the Creative Commons Attribution (CC BY) license (https:// creativecommons.org/licenses/by/ $4.0 /)$.
Department of Technology in Environmental Engineering, Faculty of Civil Engineering and Environmental Sciences, Bialystok University of Technology, 15-351 Białystok, Poland; j.leszczynski@pb.edu.pl

\begin{abstract}
This study investigated the use of weathered halloysite as an ion exchange material for ammonium removal from water. The study was conducted under static and dynamic conditions. The influence of such parameters as the preliminary concentration of ammonium ions, dose of halloysite, and $\mathrm{pH}$ was examined in periodic studies. The ion exchange capacity of weathered halloysite under various regeneration conditions such as concentration, excess of regeneration solution and the $\mathrm{pH}$ at which the regeneration was performed was also determined. The effect of flow velocity, initial $\mathrm{NH}_{4}{ }^{+}$-ions concentration was studied in column tests and the weathered halloysite's ion -exchange capacity was also determined. The best results of ammonium ion removal were obtained at $\mathrm{pH} 6$. The equilibrium isotherms were described using the Langmuir and Freundlich models. The results of periodic studies show a good fit for the data of both models, with Langmuir isotherms reflecting the removal of ammonium ions better. A good match for the data $\left(R^{2}>0.99\right)$ was provided by a pseudo second-order kinetic model. The obtained results indicate that a properly prepared halloysite can be a useful mineral for the removal of dangerous substances, such as ammonium ions, present in natural waters.
\end{abstract}

Keywords: weathered halloysite; ammonium ion; ion exchange; isotherm; kinetic model

\section{Introduction}

Ammonium nitrogen water pollution is a real issue in many areas of the world. Ammonium ions can enter water, through communal and industrial wastewater and surface runoff from fields and meadows. Ammonium nitrogen in surface water accelerates eutrophication and is harmful to aquatic organisms. Excess ammonium in water may reduce the effectiveness of disinfection and leads to the formation of disinfected byproducts [1-5]. Several biological and physicochemical processes such as air stripping, ion exchange, nitrification, and reverse osmosis are used to remove ammonium ions from water solutions $[2,6,7]$. Due to ion exchange and sorption properties, natural aluminosilicates, mainly zeolites, such as clinoptilolite, sepiolite, mordenite, and bentonite are commonly used for water and wastewater treatment [2,8-10]. The main physicochemical properties of zeolites are high sorption capacity, ion exchange capacity, and chemical and thermal resistance. Zeolites, which are crystalline hydrated logged aluminosilicates, contain micropores and are well-known ion exchangers [2,11-13]. The skeleton of the zeolite consists of symmetrically arranged aluminium oxide and silica tetrahedron, creating a stable three-dimensional structure with a negative charge neutralised by positively charged cations such as sodium and potassium. These cations can be exchanged with some of the ions present in aqueous solutions, such as heavy metals and $\mathrm{NH}_{4}{ }^{+}$ions [11,12,14]. The use of zeolites to remove ammonium ions, due to their properties and characteristics, has been widely discussed in many scientific studies worldwide [11,15,16]. Park et al. [17] achieved an $80 \%$ efficiency of $\mathrm{NH}_{4}{ }^{+}$removal using clinoptilolite from an aqueous solution containing $80 \mathrm{mg} / \mathrm{L}$. Clinoptilolite originating from New Zealand was also studied by Weatherley and Miladinovic [18]. The authors investigated zeolites' ability to remove ammonia in the presence of calcium, 
magnesium, and potassium cations. Balci and Dincel [19], obtained a $60 \%$ ammonia removal efficiency with sepiolite. Sarioglu [20] examined the efficiency of $\mathrm{NH}_{4}{ }^{+}$removal with zeolite from the Dogantepe region of Turkey. Sprynskyy et al. [21] investigated the removal of ammonium ions from synthetic aqueous solutions by raw and pre-processed natural Transcarpathian mordenite. The ion exchange capacity of mordenite relating to ammonium ions was estimated at $1.64 \mathrm{meq} / \mathrm{g}$ at an initial concentration of $1000 \mathrm{mg} \mathrm{N}$ $\mathrm{NH}_{4}{ }^{+} / \mathrm{L}$. Rozic et al. [22] examined the removal of $\mathrm{NH}_{4}{ }^{+}$ions from aqueous solutions with Croatian bentonite and clinoptilolite. The maximum efficiency of $\mathrm{NH}_{4}{ }^{+}$removal $(61.1 \%$ by weight) was achieved at the initial concentration of $100{\mathrm{mg} \mathrm{N}-\mathrm{NH}_{4}}^{+} / \mathrm{L}$. By increasing the ammonium nitrogen concentration, the removal efficiency decreased rapidly [22]. Englert and Rubio [11] removed ammonia from water using natural Chilean zeolite composed mainly of clinoptilolite and mordenite of 1.02 meq $\mathrm{NH}_{4}{ }^{+} / \mathrm{g}$ ion exchange capacity, whereas Sprynskyy et al. [23] demonstrated clinoptilolite's ability to remove heavy metals. Huang et al. [24] studied the adsorption of $\mathrm{NH}_{4}{ }^{+}$on weathered crust elution-deposited rare earth ore (WCE-DREO) and clay minerals. The obtained adsorption capacities were as follows: montmorillonite $>$ WCE-DREO $>$ halloysite $>$ illite $>$ kaolinite. The J-type Linde zeolite, synthesised from raw kaolinite by Kamyab and Williams, performed well in the sorption of ammonium ions from aqueous solutions [25]. Mahata et al. [26] used Cu-loaded aminefunctionalised $\mathrm{SiO}_{2}$ and a weakly basic ion exchange resin for $\mathrm{NH}_{4}{ }^{+}$removal. In this study, the authors obtained a high adsorption capacity for the sorbent of $9.30-21.37 \mathrm{mg} / \mathrm{g}$; the used adsorbent was successfully regenerated in $0.15 \mathrm{M} \mathrm{NaCl}$ solution.

Besides clinoptilolite, sepiolite, mordenite, and bentonite, halloysite is also used for water and sewage treatment [27]. This mineral occurs in many formations, particularly weathered volcanic rocks. Basalt spills containing large amounts of halloysite are found in Lower Silesia [28]. Halloysite is a clay mineral with a layered structure formed by $\mathrm{SiO}_{4}$ tetrahedral and $\mathrm{AlO}_{6}$ octahedral sheets. Halloysite has many industrial applications due to its well-developed specific, surface area [29,30]. It can be used as an adsorbent for treating liquids and process gases, for the production of nanocomposites, as an additive for wastewater treatment, as a catalyst in chemical processes, and as a multicomponent coagulant $[27,31-33]$. However, the available literature lacks comprehensive studies on the use of halloysite to remove $\mathrm{NH}_{4}{ }^{+}$ions from aqueous solutions by ion exchange. There are currently three active mines for this resource globally, located in the USA, New Zealand, and Poland. One of the largest deposits of halloysite in the world is located in Poland's Lower Silesia region $[28,31,32,34]$.

This paper presents a new possibility for using weathered halloysite as an ionexchange medium to remove $\mathrm{NH}_{4}{ }^{+}$ions from aqueous solutions. Ammonium ion removal with the use of aluminosilicates is an important and current research issue. However, there has been no research on halloysite. Thus, in this work, filtration beds fabricated from weathered halloysite were created and applied to remove $\mathrm{NH}_{4}{ }^{+}$ions from aqueous solutions. The ion exchange capacity, kinetics, and balance of $\mathrm{NH}_{4}{ }^{+}$removal were studied, and factors controlling the process rate were determined. Moreover, the influence of coexisting cations such as $\mathrm{Mg}^{2+}$ and $\mathrm{Ca}^{2+}$ was studied, and various operational parameters necessary for effective regeneration of the mineral were tested. Due to the lack of available studies on halloysite, the results obtained were compared to clinoptilolite, sepiolite, mordenite, and bentonite.

\section{Materials and Methods}

2.1. Reagents

$\mathrm{H}_{2} \mathrm{SO}_{4} 95-97 \%(w / w), \mathrm{HCl}, \mathrm{NaOH}$, and $\mathrm{NH}_{4} \mathrm{Cl}$ from Sigma-Aldrich, Poznań, Poland were used. 


\subsection{Characterization of Weathered Halloysite}

The mineral used for this research came from Legnica in the Lower Silesia region of Poland. The mineral obtained in the region consists mainly of weathered tertiary halloysite of the kaolinite type. The main components of the samples are halloysite and kaolinite. Small amounts of montmorillonite, illite, anatase, and quartz [28] are also present. The chemical composition of weathered halloysite, in terms of oxides, is shown in Table 1.

Table 1. Chemical characteristics of weathered halloysite.

\begin{tabular}{cc}
\hline Constituent & Value-wt.\% \\
\hline $\mathrm{SiO}_{2}$ & 35.74 \\
$\mathrm{Al}_{2} \mathrm{O}_{3}$ & 24.09 \\
$\mathrm{Fe}_{2} \mathrm{O}_{3}$ & 22.66 \\
$\mathrm{TiO}_{2}$ & 3.92 \\
$\mathrm{CaO}$ & 1.24 \\
$\mathrm{MgO}$ & 0.61 \\
$\mathrm{Na} 2$ & 0.10 \\
$\mathrm{~K}_{2} \mathrm{O}$ & 0.05 \\
Loss of ignition $\left(1000^{\circ} \mathrm{C}\right)$ & 6.64 \\
\hline
\end{tabular}

The natural mineral was initially crushed and washed with distilled water, dried at $105^{\circ} \mathrm{C}$ for $12 \mathrm{~h}$, and then grinded to a size of less than $0.1 \mathrm{~mm}$. The mineral was then mixed with distilled water and granulated. The pellets were heat-treated at $600{ }^{\circ} \mathrm{C}$ for $2 \mathrm{~h}$. Processed weathered halloysite particles of 2.1-2.5 mm granulation were used. In order to convert the processed weathered halloysite into a sodium form, the granules were mixed with a $0.5 \mathrm{~mol} \mathrm{NaCl}$ solution at $\mathrm{pH} 10.5$ and shaken for $24 \mathrm{~h}$, then washed with distilled water and finally dried at $60^{\circ} \mathrm{C}$. According to the studies, the regeneration of zeolites with alkaline $\mathrm{NaCl}$ solution increases regeneration efficiency and reduces the required volume of regeneration solution $[35,36]$.

\subsection{Chemical Analyses}

Analytical tests of water samples included the following determinations: $\mathrm{pH}$, alkalinity, conductivity, $\mathrm{NH}_{4}{ }^{+}, \mathrm{Mg}^{2+}, \mathrm{Ca}^{2+}, \mathrm{Na}^{+}$, and $\mathrm{K}^{+}$. All analyses were conducted according to the standard APHA procedure [37]. $\mathrm{NH}_{4}{ }^{+}$concentration was determined by the standard Nessler method using a HACH DR 4000 spectrophotometer (Hach Lange GmbH, Düsseldorf, Germany). Calcium, magnesium, sodium, and potassium were determined by Atomic Absorption Spectrometry (AAS). The chemical composition of clay samples was determined with a TXRF (Total X-ray Reflection Fluorescence, S2 PICOFOX, Bruker, Germany).

Statistical analysis included the calculation of mean value and standard deviation. The presented test results are the mean of at least three repetitions, and the standard deviation of the measured values did not exceed $5 \%$.

\subsection{Experimental Procedures}

The studies were conducted periodically under flow conditions using model water prepared from distilled and treated surface water (tap water). An aqueous solution of $\mathrm{NH}_{4}{ }^{+}$in distilled and tap water was prepared from $\mathrm{NH}_{4} \mathrm{Cl}$. The surface water came from the Supraśl River situated near the city of Białystok in Poland. The composition of the treated water is presented in Table 2. 
Table 2. Characterization of tap water.

\begin{tabular}{cc}
\hline Parameter & Value \\
\hline $\mathrm{pH}$ & 7.4 \\
Conductivity $(\mu \mathrm{S} / \mathrm{cm})$ & 450 \\
Alkalinity $\left(\mathrm{mg} \mathrm{CaCO}_{3} / \mathrm{L}\right)$ & 185.2 \\
Total hardness $\left(\mathrm{mg} \mathrm{CaCO}_{3} / \mathrm{L}\right)$ & 246.3 \\
$\mathrm{KMnO}_{4}(\mathrm{mg} \mathrm{O} / \mathrm{L})$ & 2.3 \\
$\mathrm{Ca}^{2+}(\mathrm{mg} / \mathrm{L})$ & 76.5 \\
$\mathrm{Mg}^{2+}(\mathrm{mg} / \mathrm{L})$ & 13.2 \\
$\mathrm{Na}^{+}(\mathrm{mg} / \mathrm{L})$ & 9.6 \\
$\mathrm{~K}^{+}(\mathrm{mg} / \mathrm{L})$ & 1.3 \\
\hline
\end{tabular}

\subsubsection{Batch Test}

The effectiveness of ammonium ion removal was periodically tested depending on contact time, mineral dose, $\mathrm{NH}_{4}{ }^{+}$concentration, and $\mathrm{pH}$. The volume of solutions in individual experiments was $500 \mathrm{~mL}$. The influence of initial $\mathrm{NH}_{4}{ }^{+}$concentration was studied in the range of $5,10,15,20$, and $30 \mathrm{mg} / \mathrm{L}$ using a $15 \mathrm{~g}$ weathered halloysite balance. The removal efficiency of $\mathrm{NH}_{4}{ }^{+}$depending on the dose of weathered halloysite was tested using $6,9,18,27$, and $36 \mathrm{~g}$ of mineral. The $\mathrm{NH}_{4}{ }^{+}$removal efficiency depending on $\mathrm{pH}$ was tested in a range from 4 to 10 at a concentration of $20 \mathrm{mg} \mathrm{NH}_{4}{ }^{+} / \mathrm{L}$ and a weathered halloysite dose of $15 \mathrm{~g}$. The effect of contact time was tested with an ammonium ion concentration in the range of 10 to $60 \mathrm{mg} / \mathrm{L}$ and a weathered halloysite dose of $5 \mathrm{~g}$. During the experiment, at specific intervals, $5 \mathrm{~mL}$ samples were taken for analytical tests.

During the study, properly prepared doses of the regenerated mineral were introduced into prepared aqueous solutions and shaken for $45 \mathrm{~min}$. The time was determined based on known research and literature. Dimova et al. [38] discovered that the uptake of $\mathrm{NH}_{4}{ }^{+}$ ions by aluminosilicate is a fast reaction, which occurs in less than $15 \mathrm{~min}$. After shaking, the sample was filtered through a microporous membrane filter $(0.45 \mu \mathrm{m})$, and the residual content of the $\mathrm{NH}_{4}{ }^{+}$ion in the sample was tested. The concentration in the solid phase was calculated using the equation shown in Equation (1) [39]:

$$
\mathrm{q}_{\mathrm{e}}=\frac{\left(\mathrm{C}_{\mathrm{o}}-\mathrm{C}_{\mathrm{e}}\right) \mathrm{V}}{\mathrm{M}}
$$

where $\mathrm{q}_{\mathrm{e}}(\mathrm{mg} / \mathrm{g})$ is the total amount of adsorbed $\mathrm{NH}_{4}{ }^{+}$ions $(\mathrm{mg} / \mathrm{g}), \mathrm{C}_{\mathrm{e}}$ and $\mathrm{C}_{\mathrm{o}}$ are the equilibrium and initial concentrations of $\mathrm{NH}_{4}{ }^{+}$ions $(\mathrm{mg} / \mathrm{L})$, respectively. $\mathrm{M}$ is the adsorbent weight $(\mathrm{g})$, and $\mathrm{V}$ is the solution volume (L).

\subsubsection{Regeneration}

The influence of regeneration conditions on ion exchange capacity was tested at $\mathrm{NH}_{4}{ }^{+}$ $500 \mathrm{mg} / \mathrm{L}$ and a weathered halloysite dose of $5 \mathrm{~g}$ in $250 \mathrm{~mL}$ samples. Solutions of 3 and $5 \% \mathrm{NH}_{4} \mathrm{Cl}$ were used for regeneration using the excess of three and five times the ion exchange volume. The tests were performed at $\mathrm{pH}$ levels of 9 and 10.5 of $\mathrm{NH}_{4} \mathrm{Cl}$ solution, determined with $\mathrm{NaOH}$.

\subsubsection{Column Test}

In the column test's parameters, such as initial $\mathrm{NH}_{4}{ }^{+}$concentration and flow rate, were examined. The influence of water hardness on the removal efficiency of $\mathrm{NH}_{4}{ }^{+}$ions was also investigated, and the total and working ion exchange capacity of the weathered halloysite was determined. For the experiments, a glass filtration column with a bed volume of $67 \mathrm{~mL}$ and a diameter of $18 \mathrm{~mm}$ was used. The evaporated model water was fed by a peristaltic pump from top to bottom, keeping the water level in the column constant. The column was filled with granules with a diameter of 2.1-2.4 $\mathrm{mm}$. Under flow conditions, the removal of ammonium ions was studied depending on the surface load of the filter column at ranges of $4,6,8$, and $10 \mathrm{~m} / \mathrm{h}$ and the initial concentration of $\mathrm{NH}_{4}{ }^{+}$ions in the range of $5-50 \mathrm{mg} / \mathrm{L}$. 
Exhaustion of the ion exchange bed was tested at a hydraulic load of $6 \mathrm{~m} / \mathrm{h}$. The test was conducted until breakthrough, and until the ion exchange capacity was completely exhausted, i.e., until the equilibrium concentration in the effluent was reached.

\section{Results and Discussion}

\subsection{Batch Study}

\subsubsection{Influence of Contact Time and Initial $\mathrm{NH}_{4}{ }^{+}$Concentration}

The efficiency of ion exchange depending on the reaction time and initial concentration of ammonium ions is shown in Figure 1. As illustrated in Figure 1, the removal rate of ammonium ions increases in the initial $20 \mathrm{~min}$, then gradually equalises and finally reaches equilibrium after $40 \mathrm{~min}$. Changes in the $\mathrm{NH}_{4}{ }^{+}$removal rate in the initial phase of the process may result from many free active adsorbent sites. Then the removal rate of ammonium ions decreases. On the other hand, an increase in the ion exchange efficiency with an increasing initial $\mathrm{NH}_{4}{ }^{+}$ion concentration may result from an increase in the driving force, which is measured by the concentration of the solution, especially in the initial stage of the process, where there is a large difference in the concentration of the ammonium ion [39-43].

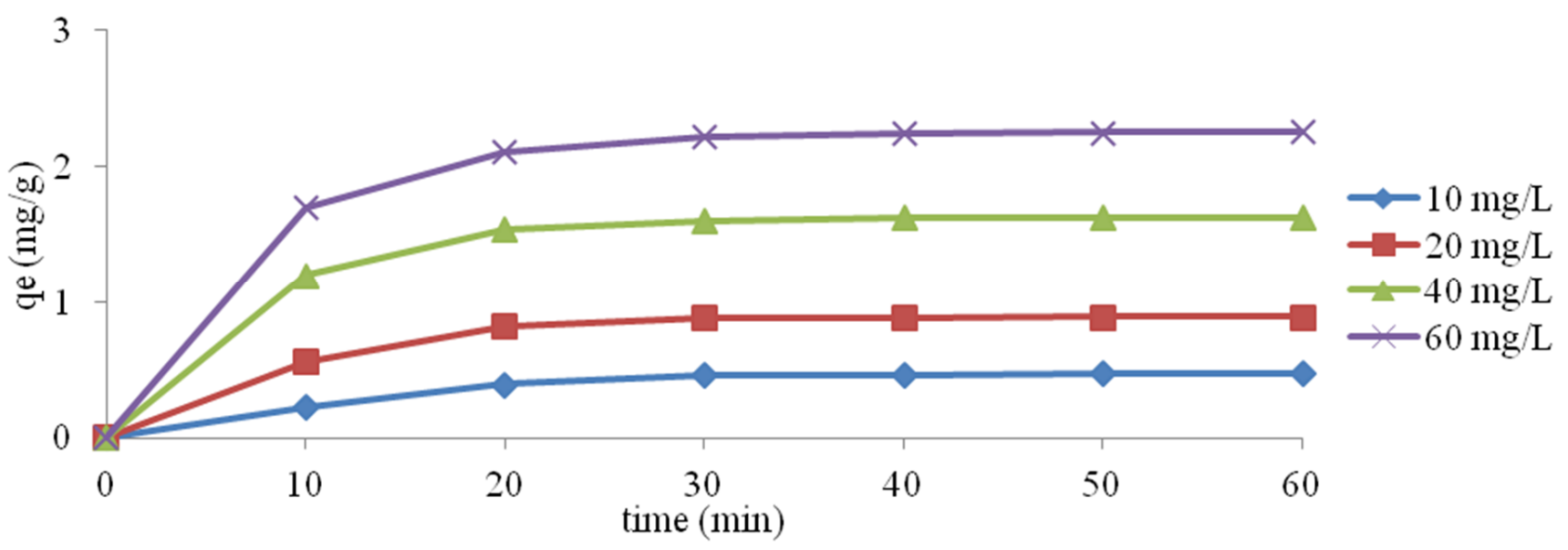

Figure 1. Influence of initial concentration and contact time on the exchange of $\mathrm{NH}_{4}{ }^{+}$ions.

\subsubsection{Influence of $\mathrm{pH}$}

The influence of $\mathrm{pH}$ in the studied range of 4-10 on the change in ammonium ion removal efficiency is shown in Figure 2. The highest reduction of $\mathrm{NH}_{4}{ }^{+}$removal was obtained at a $\mathrm{pH}$ of 6 . A slightly smaller effect was observed at $\mathrm{pH}$ 7. Similar properties were shown in clinoptilolite studied by Du et al. [35]. However, in these authors' studies, a substantial decrease in the efficiency of the process was already noted at a $\mathrm{pH}$ of 7 . The influence of the reaction on the efficiency of $\mathrm{NH}_{4}{ }^{+}$ion removal is mainly related to the $\mathrm{pH}$-dependent form of ammonium nitrogen. At a $\mathrm{pH}$ above 9, the $\mathrm{NH}_{4}{ }^{+}$ions change into the gaseous form of $\mathrm{NH}_{3}$, which do not undergo ion exchange when deprived of charge. A drop in $\mathrm{pH}$ below 6 increases the concentration of $\mathrm{H}^{+}$ions, which become competitive with $\mathrm{NH}_{4}{ }^{+}$ions [41]. 


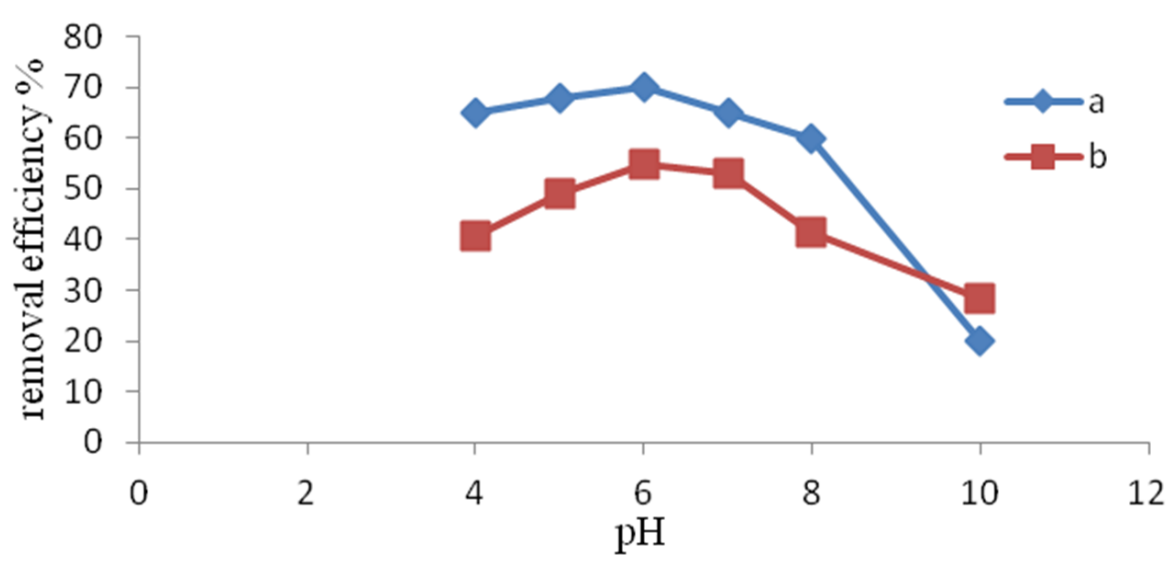

Figure 2. Influence of $\mathrm{pH}$ on the efficiency of $\mathrm{NH}_{4}{ }^{+}$removal from (a) distilled water, (b) tap water.

\subsubsection{Ammonium Exchange Isotherm}

The removal of $\mathrm{NH}_{4}{ }^{+}$ions by weathered halloysite was interpreted based on Langmuir and Freundlich isotherms. The isotherms show the dependence between the quantity of substance absorbed by the adsorbent mass units and adsorbate equilibrium concentrations. The models can be used to describe the behaviour of the ion exchange mass at equilibrium for various ammonium ion concentrations [20,44].

Freundlich's isotherm is commonly used to characterise adsorption properties on heterogeneous surfaces. Freundlich's equation usually takes the form of $\mathrm{q}_{e}=\mathrm{KC}_{\mathrm{e}} 1 / n$ ( $\mathrm{q}_{\mathrm{e}}$ is the quantity of $\mathrm{NH}_{4}{ }^{+}$absorbed per unit mass of adsorbent), $\mathrm{C}_{\mathrm{e}}$ is the equilibrium concentration of $\mathrm{NH}_{4}{ }^{+}$residual in solution, $\mathrm{n}$ and $\mathrm{K}$ are both empirical constants. The linear form of the equation is shown in Equation (2): $[35,39]$

$$
\log q_{\mathrm{e}}=\log \mathrm{K}+\frac{1}{n} \log \mathrm{C}_{\mathrm{e}}
$$

The Langmuir equation describes a case where only one adsorption layer is formed on the adsorbent surface. The Langmuir theory presumes that the adsorbent surface is homogeneous, and the possibility of creating multiple layers is excluded. A particle cannot move freely on the surface, and the lateral interactions between the particles are irrelevant [45-47]. The Langmuir equation in linear form is shown in Equation (3) [39]:

$$
\frac{C_{e}}{q_{e}}=\frac{1}{q_{m} K_{L}} \frac{C_{e}}{q_{m}}
$$

where $\mathrm{q}_{\mathrm{e}}$ represents the amount of dissolved matter absorbed per unit weight of adsorbent in equilibrium $(\mathrm{mg} / \mathrm{g})$, parameter $\mathrm{q}_{\mathrm{m}}$ represents the maximum sorption capacity of the adsorbent, i.e., the maximum amount of ions needed to fill the monolayer $(\mathrm{mg} / \mathrm{g})$. $\mathrm{C}_{\mathrm{e}}$ represents the equilibrium concentration of the substance dissolved in a solution $(\mathrm{mg} / \mathrm{L})$, and $\mathrm{K}_{\mathrm{L}}$ represents the Langmuir constant $(\mathrm{L} / \mathrm{mg})$. The $\mathrm{q}_{\mathrm{m}}$ and $\mathrm{K}_{\mathrm{L}}$ factors in the Langmuir equation are determined by the slope and intersection point of the graph $\mathrm{Ce} / \mathrm{q}_{\mathrm{e}}$ to $\mathrm{C}_{\mathrm{e}}$, respectively. However, the values of Freundlich $\mathrm{K}$ and Langmuir $\mathrm{K}_{\mathrm{L}}$ constants are a measurement of the relative adsorption capacity of $\mathrm{NH}_{4}{ }^{+}$ions [18]. The experimental results shown in Figures 3-6 indicate that both models fit well with the experimental data. The coefficients $\mathrm{K}, \mathrm{K}_{\mathrm{L}}, \mathrm{q}_{\mathrm{m}}$ and $(1 / n)$, as well as the corresponding correlation factors for studies conducted with distilled and tap water, are presented in Table 3. 


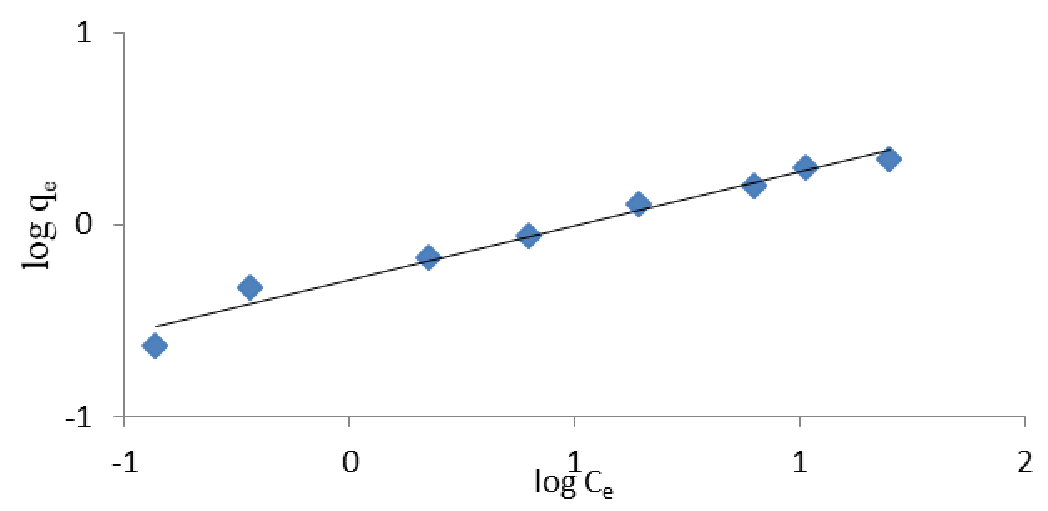

Figure 3. Freundlich linearised isotherm for the removal of ammonium ions from $\mathrm{NH}_{4} \mathrm{Cl}$ solution in distilled water.

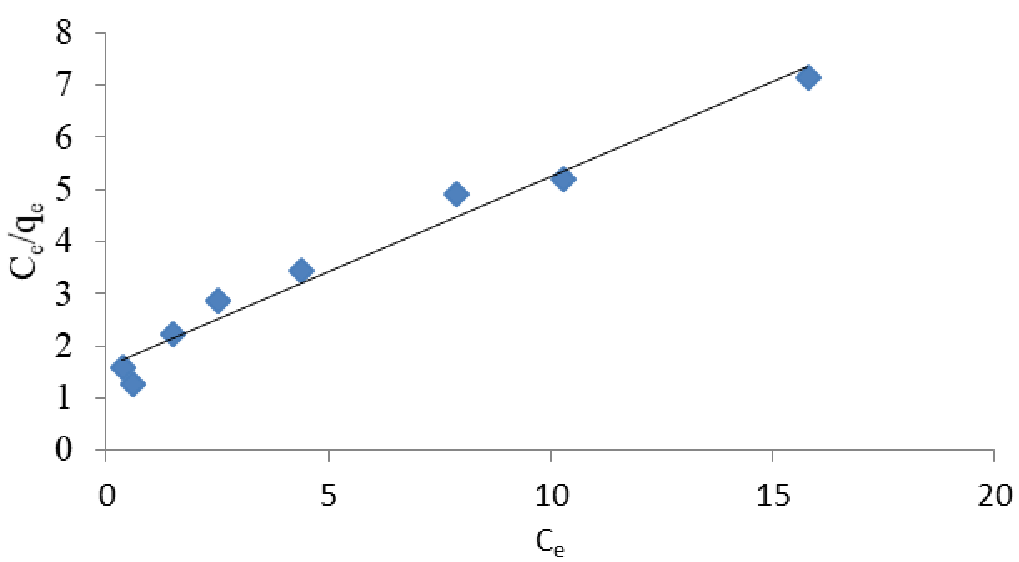

Figure 4. Langmuir linearised isotherm for the removal of ammonium ions from $\mathrm{NH}_{4} \mathrm{Cl}$ solution in distilled water.

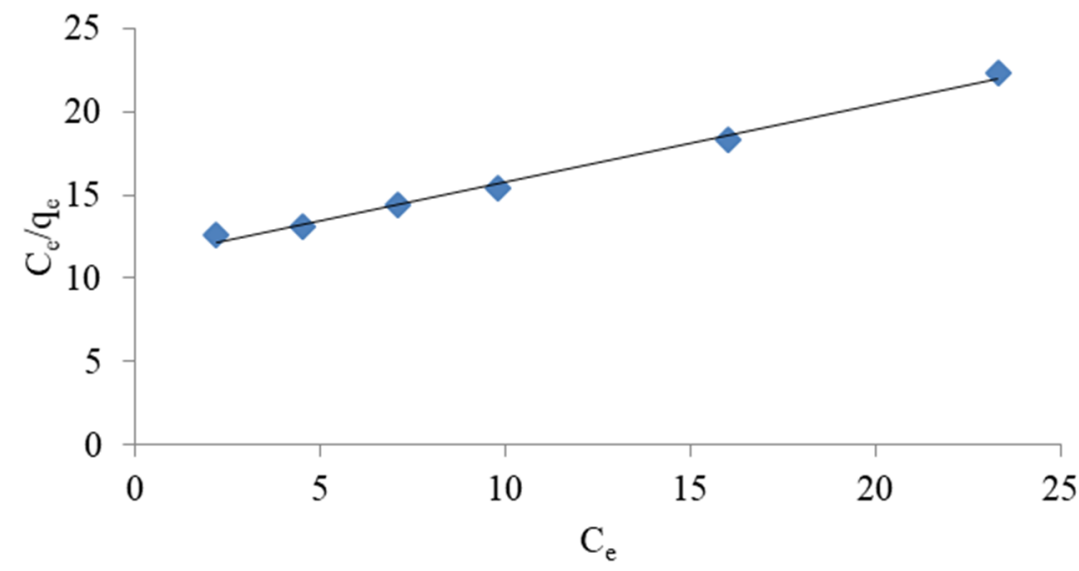

Figure 5. Langmuir linearised isotherm for the removal of ammonium ions from $\mathrm{NH}_{4} \mathrm{Cl}$ solution in tap water. 
1

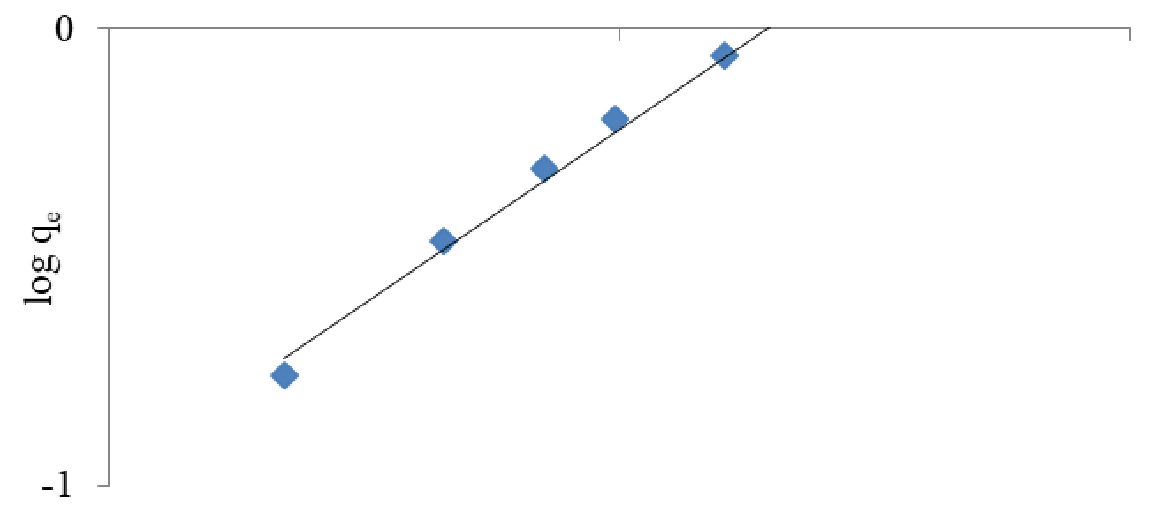

$\log \mathrm{C}_{\mathrm{e}}$

Figure 6. Freundlich linearised isotherm for the removal of ammonium ions from $\mathrm{NH}_{4} \mathrm{Cl}$ solution in tap water.

Table 3. Langmuir and Freundlich model parameters.

\begin{tabular}{ccccccc}
\hline \multirow{2}{*}{ Type of Sample } & \multicolumn{3}{c}{ Freundlich } & \multicolumn{3}{c}{ Langmuir } \\
\cline { 2 - 7 } & $\boldsymbol{K}$ & $\mathbf{1} / \boldsymbol{n}$ & $\mathbf{R}^{\mathbf{2}}$ & $\boldsymbol{q}_{\mathbf{m}} \mathbf{( \mathbf { m g } / \mathbf { g } )}$ & $\boldsymbol{K}_{\mathbf{L}}(\mathbf{L} / \mathbf{m g})$ & $\mathbf{R}^{\mathbf{2}}$ \\
\hline distilled water & 0.51 & 0.57 & 0.971 & 2.75 & 0.226 & 0.974 \\
tap water & 0.11 & 0.76 & 0.987 & 2.139 & 0.042 & 0.993 \\
\hline
\end{tabular}

It can be seen that a good match was achieved for both models $\left(R^{2}>0.97\right)$. A better match for both models was specifically obtained in studies using tap water. Comparing the results obtained, however, it seems that the Langmuir isotherm better represents the adsorption capacity of halloysite and is more appropriate for use in ammonium ion removal studies. A better match of the Langmuir isotherm $\left(R^{2}=0.927-0.969\right)$ with Turkish clinoptilolite is also provided by Karadag et al. [43]. Zamri et al. [48] observed that Freundlich's model was the best fit to remove $\mathrm{NH}_{4}{ }^{+}$ions from ion exchange resin, while Langmuir's model better reflected the removal of heavy metals.

\subsubsection{Kinetic Study}

The study of kinetic parameters helps predict the rate of adsorption. Selected models of adsorption kinetics were used to study the kinetics of ammonium ion removal, namely the pseudo first-order, pseudo second-order, and intramolecular diffusion model. The pseudo first-order model equation is described as follows in Equation (4) [43]:

$$
\log \left(\mathrm{q}_{\mathrm{e}}-\mathrm{q}_{\mathrm{t}}\right)=\log \mathrm{q}_{\mathrm{e}}-\frac{\mathrm{k}_{1}}{2.303} \mathrm{t}
$$

The pseudo -first order reaction rate constant $k_{1}(1 / \mathrm{min})$ is shown in Table 4.

Table 4. Pseudo first-order, pseudo second-order, and diffusion kinetic models.

\begin{tabular}{ccccccc}
\hline \multirow{2}{*}{ Initial Concentration $\left(\mathrm{mg} \mathrm{NH}_{\mathbf{4}}{ }^{+} / \mathbf{L}\right)$} & \multicolumn{2}{c}{ Pseudo First-Order } & \multicolumn{2}{c}{ Pseudo Second-Order } & \multicolumn{2}{c}{ Diffusion } \\
\cline { 2 - 6 } & $\mathbf{k}_{\mathbf{1}} \mathbf{( 1 / \mathbf { m i n } )}$ & $\mathbf{R}^{\mathbf{2}}$ & $\mathbf{k}_{\mathbf{2}} \mathbf{( g / \mathbf { m g } \mathbf { m i n } )}$ & $\mathbf{R}^{\mathbf{2}}$ & $\mathbf{R}^{\mathbf{2}}$ \\
\hline 20 & 0.0599 & 0.91 & 0.19 & 0.99 & 0.73 \\
\hline
\end{tabular}


The linear form for the pseudo second-order equation is described as follows in Equation (5) [43]:

$$
\frac{\mathrm{t}}{\mathrm{q}_{\mathrm{t}}}=\frac{1}{\mathrm{k}_{2} \mathrm{q}_{\mathrm{e}}^{2}}+\frac{1}{\mathrm{q}_{\mathrm{e}}} \mathrm{t}
$$

The pseudo-second order reaction rate, constant $\mathrm{k}_{2}$ (g/mg min), is shown in Table 4 . Intramolecular diffusion can be represented by Equation (6) [43]:

$$
\mathrm{q}_{\mathrm{t}}=\mathrm{k}_{\mathrm{d}} \mathrm{t}^{0.5}+\mathrm{C}
$$

where $\mathrm{q}_{\mathrm{t}}$ is the absorbed substance in ( $\left.\mathrm{mg} / \mathrm{g} \mathrm{min}\right), \mathrm{k}_{\mathrm{d}}$ represents the intramolecular diffu-

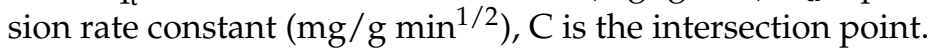

According to the study, a higher correlation coefficient $\left(R^{2}\right)$ was obtained for the pseudo second-order model and intramolecular diffusion. The data shown in Table 4 and Figure 7 demonstrated a fairly good fit $\left(\mathrm{R}^{2}>0.99\right)$ with the pseudo second-order kinetic model; this indicates that this model describes the adsorption kinetics of $\mathrm{NH}_{4}{ }^{+}$ions by halloysite. Therefore, this model is widely used to describe the kinetics of sorption and ion exchange processes and often provides the best fitting results [41,48,49].

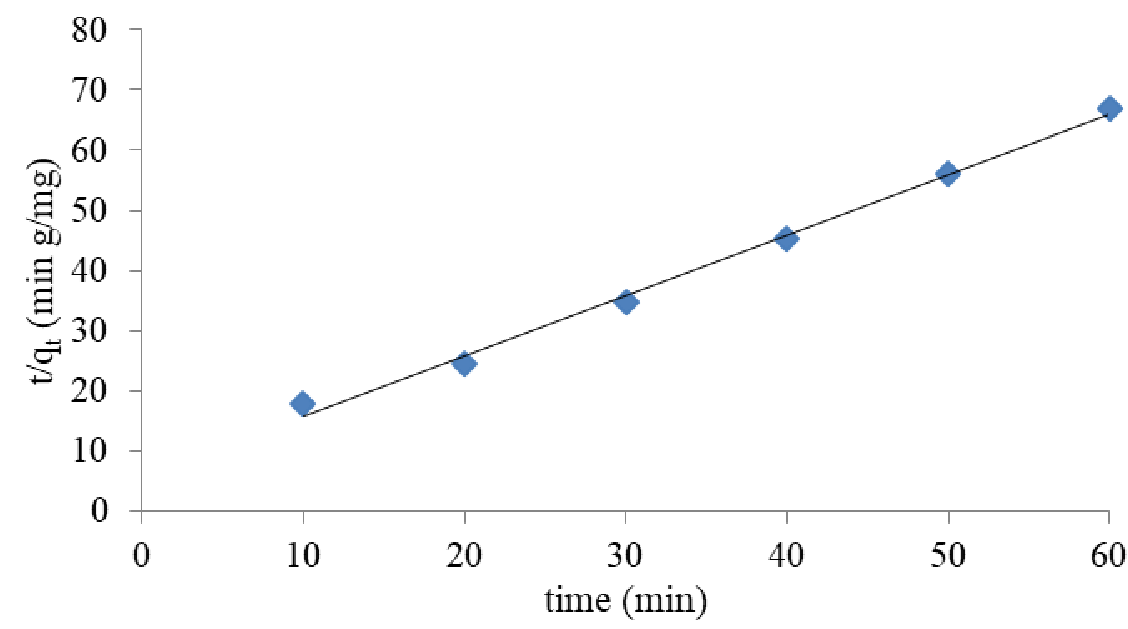

Figure 7. Second-order pseudo kinetic diagram for $\mathrm{NH}_{4}{ }^{+}$exchange.

According to the intramolecular diffusion model, as shown in Figure 8, the ammonium exchange involves two stages (linear regions); this suggests that the process may be conducted by surface sorption and intramolecular diffusion [45]. Karadag et al. [43] have stated that the first linear part reflects the diffusion effect in the boundary layer, and the last linear part may be due to the intramolecular diffusion effect.

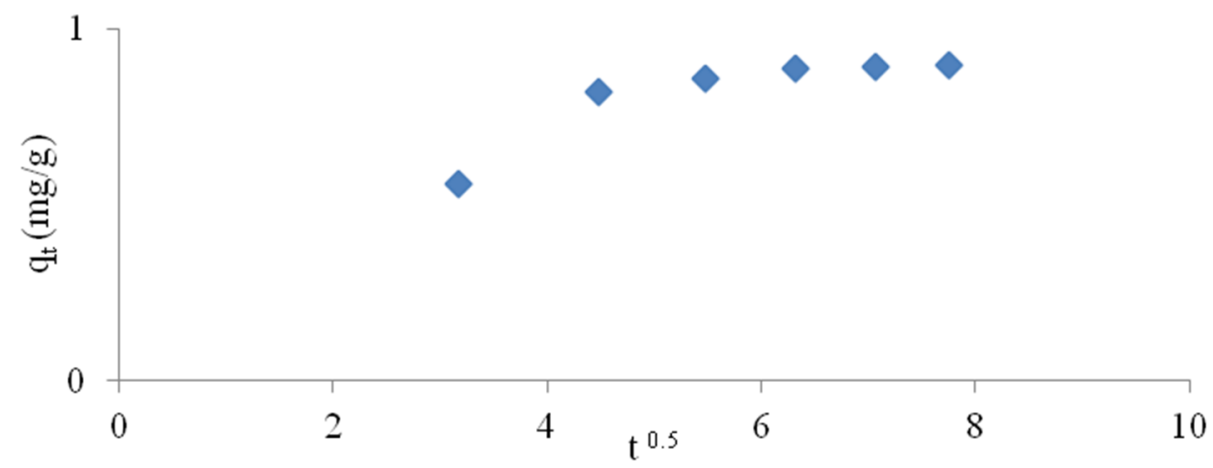

Figure 8. Intraparticle diffusion kinetic plot. 


\subsubsection{Regeneration}

The results of weathered halloysite regeneration are presented in Figure 9. It was found that the highest ion exchange capacity relating to ammonium ions was obtained with $5 \% \mathrm{NaCl}$ regeneration and a five-fold excess. The study also showed that apart from the $\mathrm{NaCl}$ concentration, the excess of regeneration solution is also an important parameter during regeneration. Regeneration with a $\mathrm{NaCl}$ solution of $\mathrm{pH} 10.5$ significantly increased the ion exchange capacity of the mineral, especially when using a smaller excess of the regenerating agent. The obtained maximum ion exchange capacity of weathered halloysite $(0.99 \mathrm{meq} / \mathrm{g})$ is similar to that of clinoptilolite $1.03 \mathrm{mmol} / \mathrm{g}$ provided by Du et al. [35]. Sprynskyy et al. [21], on the other hand, evaluated the ion exchange capacity of Carpathian mordenite relating to ammonium ions at $1.64 \mathrm{meq} / \mathrm{g}$ at the initial N-NH${ }_{4}^{+} 1000 \mathrm{mg} / \mathrm{L}$. Caradag et al. [43] obtained $6.32 \mathrm{mg} \mathrm{N-NH_{4 }}{ }^{+} / \mathrm{g}$ for Turkish clinoptilolite. Widiastuti et al. [36] obtained $3.89 \mathrm{mg} \mathrm{N}-\mathrm{NH}_{4}{ }^{+} / \mathrm{g}$ for Australian zeolite. Wang et al. [47] at $\mathrm{NH}_{4}{ }^{+}$ content of $10 \mathrm{ppm}$ obtained $1.21 \mathrm{mmol} / \mathrm{g}$ for mordenite.

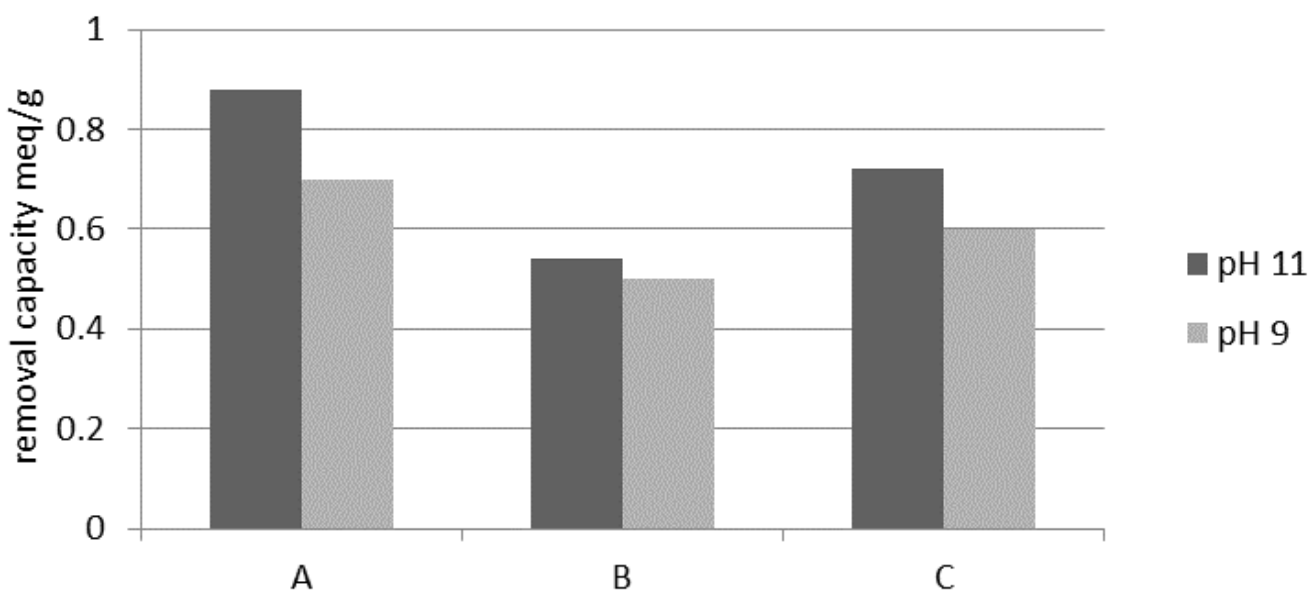

Figure 9. Weathered halloysite ion exchange capacity depending on $\mathrm{pH}$ excess and a concentration of the regenerating solution $\mathrm{NaCl}$ : A, $5 \%$ excess $5 ; \mathrm{B}, 3 \%$ excess $3 ; \mathrm{C}, 3 \%$ excess 5 .

\subsection{Column Study}

Under flow conditions, the ion exchange efficiency was investigated depending on the filtration speed and initial concentration of ammonium ions. According to the studies presented in Figure 10, the efficiency of $\mathrm{NH}_{4}{ }^{+}$ion removal depends on both the filtration speed and the initial concentration. In the case of filtration at a speed of $4 \mathrm{~m} / \mathrm{h}$, the effect of ammonium ion removal increased with the initial concentration, reaching $95.04 \%$ at $12 \mathrm{mg}$ $\mathrm{NH}_{4}{ }^{+} / \mathrm{L}$ and $99.5 \%$ at $48 \mathrm{mg} \mathrm{NH}{ }^{+} / \mathrm{L}$. During filtration at a speed of 6 and $8 \mathrm{~m} / \mathrm{h}$, the highest effect of $\mathrm{NH}_{4}{ }^{+}$removal was obtained for the concentration of $24 \mathrm{mg} \mathrm{NH}_{4}{ }^{+} / \mathrm{L}$. A decrease in process efficiency at higher ammonium ion concentrations was observed in both cases. At a filtration speed of $10 \mathrm{~m} / \mathrm{h}$, the maximum process efficiency was obtained with an initial concentration of $18 \mathrm{mg} \mathrm{NH}_{4}{ }^{+} / \mathrm{L}$. Higher process efficiencies in the range of lower filtration rates are directly related to the retention time, which was also shown by $\mathrm{Du}$ et al. [35]. The results of tests using tap water are presented in Figure 11. At a filtration speed of $4 \mathrm{~m} / \mathrm{h}$, the process efficiency increased with the increase in initial $\mathrm{NH}_{4}{ }^{+}$ concentration from $93.1 \%$ to $96.1 \%$. In the second case (filtration speed $6 \mathrm{~m} / \mathrm{h}$ ), the highest removal effect of $93.51 \%$ was obtained at the initial concentration of $24 \mathrm{mg} \mathrm{NH}_{4}{ }^{+} / \mathrm{L}$. At the concentration of $48 \mathrm{mg} \mathrm{NH}_{4}{ }^{+} / \mathrm{L}$, the process efficiency was lower and amounted to $91.8 \%$. For the remaining filtration speeds, the effect of $\mathrm{NH}_{4}{ }^{+}$ion removal decreased with increasing initial concentrations from $91.13 \%$ to $84.4 \%$ at $7 \mathrm{~m} / \mathrm{h}$ and from 88.8 to $75.8 \%$ at $10 \mathrm{~m} / \mathrm{h}$. The decrease in ammonium ion removal efficiency in prepared tap water is mainly related to the presence of calcium and magnesium ions, which was confirmed by Transcarpathian clinoptilolite studies performed by Sprynskyy et al. [7] and Wang et al. [47]. 
Mazloomi et al. [40] showed the following ion exchange sequence $(\mathrm{K}>\mathrm{Na}>\mathrm{Ca}>\mathrm{Mg})$ for Iranian zeolites.

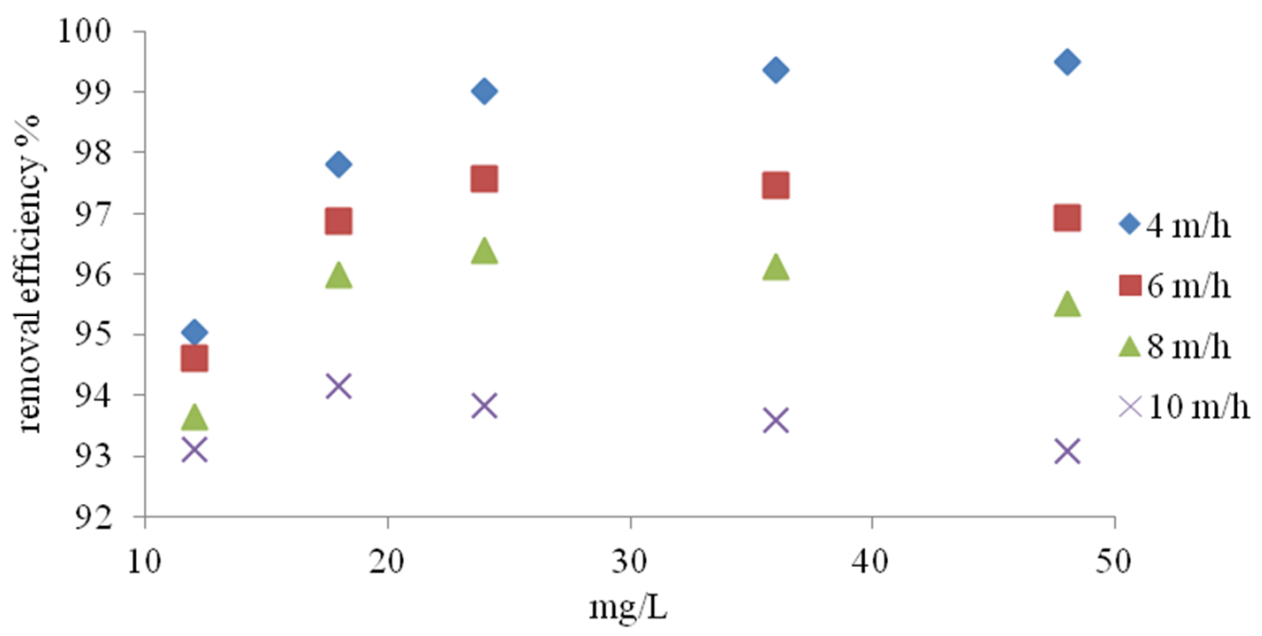

Figure 10. Effect of flow rate on the removal efficiency of different ammonia concentrations from $\mathrm{NH}_{4} \mathrm{Cl}$ solution in distilled water.

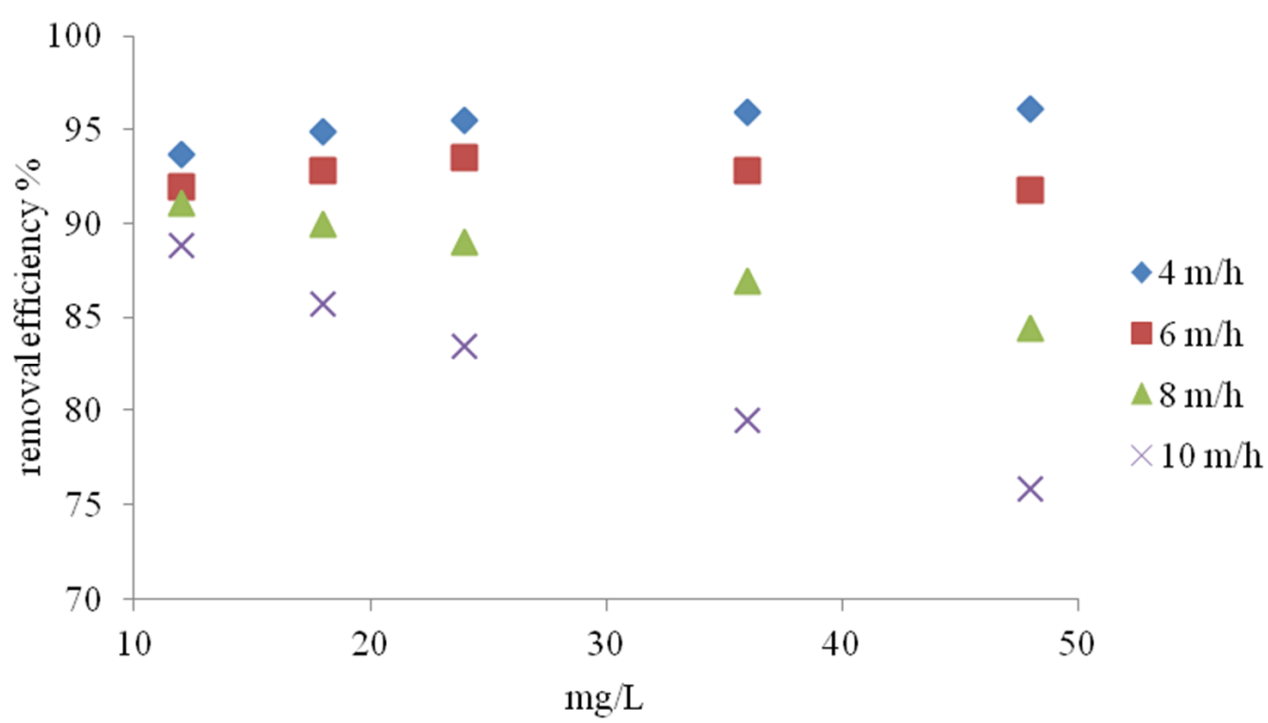

Figure 11. Effect of flow rate on the removal efficiency of different ammonia concentrations from $\mathrm{NH}_{4} \mathrm{Cl}$ solution in tap water.

The relationship between the removal of $\mathrm{Ca}^{2+}$ and $\mathrm{Mg}^{2+}$ and $\mathrm{NH}_{4}{ }^{+}$ions depending on the filtration rate is shown in Figure 12. According to the study, the removal efficiency of $\mathrm{Ca}^{2+}$ and $\mathrm{Mg}^{2+}$ decreased with the increasing filtration rate and initial $\mathrm{NH}_{4}{ }^{+}$concentration. The obtained relationships indicate that weathered halloysite has a higher efficiency in removing ammonium ions than those causing water hardness at higher filtration speeds and higher initial $\mathrm{NH}_{4}{ }^{+}$concentrations. 


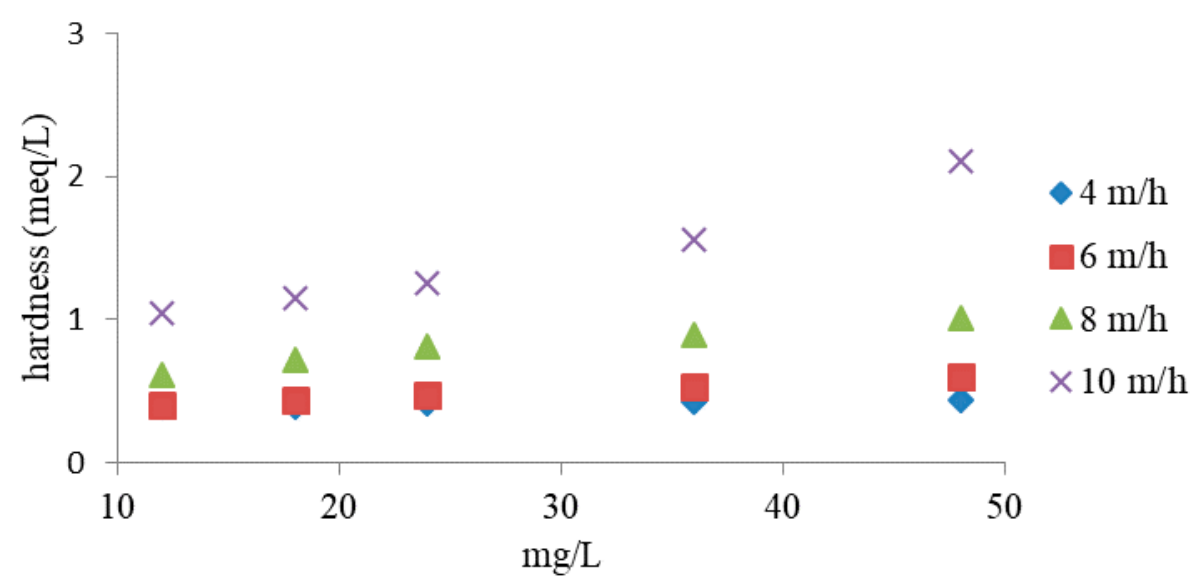

Figure 12. Relationship between initial ammonia concentration, hardness degree, and flow rate.

Figure 13 shows the exhaustion curve of an ion exchange column packed with a weathered halloysite at a flow rate of $6 \mathrm{~m} / \mathrm{h}$ and an initial ammonium ion concentration of $30 \mathrm{mg} \mathrm{NH}_{4}{ }^{+} / \mathrm{L}$. It was found that the total ion exchange capacity of the weathered halloysite obtained under dynamic conditions was $20 \mathrm{mg} / \mathrm{g}$. The breakthrough of the halloysite bed was observed after passing $10 \mathrm{~L}$ of model water. The calculated ion exchange capacity was $5.0 \mathrm{mg} / \mathrm{g}$. Du et al [35] determined that the CEC of clinoptilolite after reaching a concentration of $5 \mathrm{mg} \mathrm{N}-\mathrm{NH}_{4}{ }^{+} / \mathrm{L}$ with an initial value of $25 \mathrm{mg} \mathrm{N}-\mathrm{NH}_{4}{ }^{+} / \mathrm{L}$, to be 7.74, 6.95 and $5.81 \mathrm{mg} / \mathrm{g}$ for flow rates of 6,12 and $24 \mathrm{BV} / \mathrm{h}$, respectively.

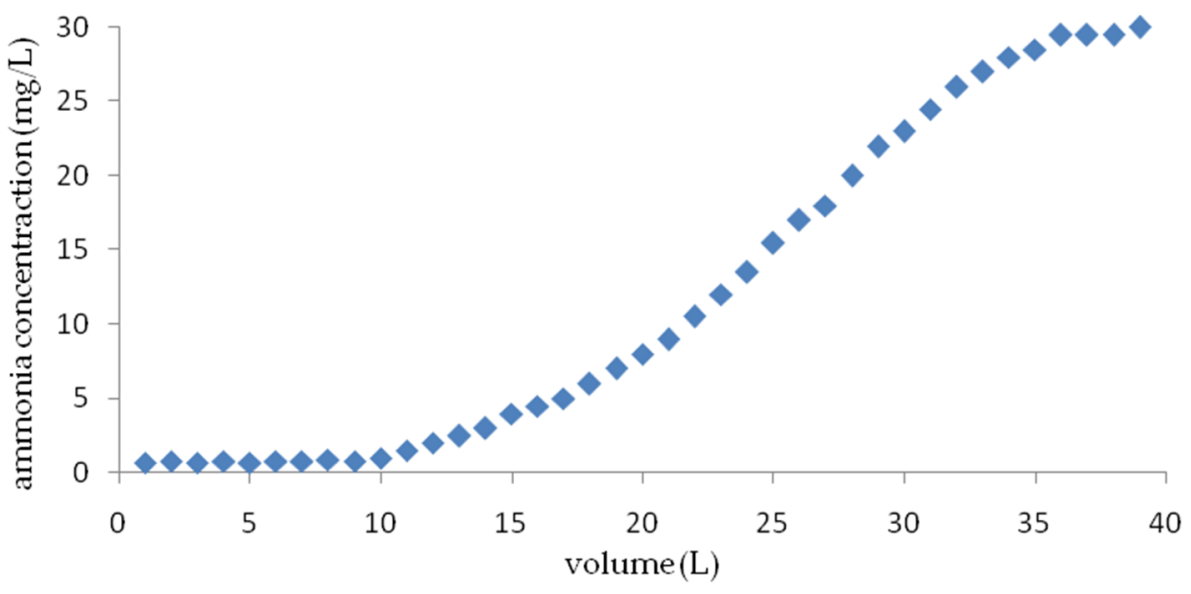

Figure 13. The breakthrough curve of ammonium ion removal by halloysite at an initial $\mathrm{NH}_{4}{ }^{+}$ion concentration of $30 \mathrm{mg} / \mathrm{L}$.

\section{Conclusions}

- The studies showed the usefulness of weathered halloysite to remove ammonium nitrogen from aqueous solutions. In addition, the results obtained confirm that properly prepared halloysite has a high ammonia removal efficiency, comparable to other aluminosilicates.

- In a periodic study, the effectiveness of $\mathrm{NH}_{4}{ }^{+}$removal increased with the initial concentration, while the presence of hardness causing ions $\left(\mathrm{Ca}^{2+}, \mathrm{Mg}^{2+}\right)$ in tap water decreased the effectiveness of the process.

- The removal of $\mathrm{NH}_{4}{ }^{+}$also depended on the $\mathrm{pH}$ of the aqueous solution $\mathrm{NH}_{4} \mathrm{Cl}$. The best result was obtained at a $\mathrm{pH}$ of 6 , although a similar process efficiency was also recorded at $\mathrm{pH} 7$. In the studied range of $\mathrm{pH} 4,5$, as well as 8, 9, the efficiencies of ammonium ion removal significantly decreased.

- Under dynamic conditions, the removal of $\mathrm{NH}_{4}{ }^{+}$ions was closely related to the flow velocity and initial $\mathrm{NH}_{4}{ }^{+}$concentration. In the study, it was observed that at a higher 
filtration speed and higher initial $\mathrm{NH}_{4}{ }^{+}$concentration, weathered halloysite exhibited higher $\mathrm{NH}_{4}{ }^{+}$removal efficiency than the ions causing water hardness.

- The experimental data described by the Langmuir and Freundlich isotherms provide the appropriate correlation coefficient value $\left(R^{2}>0.9\right)$. However, the Langmuir isotherm described the removal of ammonium ions by weathered halloysite slightly better.

- The pseudo second-order kinetic model provided the best correlation with experimental data for all systems tested.

- The weathered halloysite exchange capacity for $\mathrm{NH}_{4}{ }^{+}$ions was evaluated as 0.99 meq/g at the initial $\mathrm{NH}_{4}{ }^{+}$concentration of $500 \mathrm{mg} / \mathrm{L}$. The highest capacity was obtained during weathered halloysite regeneration with a $5 \% \mathrm{NaCl}$ solution using a five-fold excess. Apart from $\mathrm{NaCl}$ concentration, the excess of the regeneration solution was also an important parameter during the regeneration. Regeneration with a $\mathrm{NaCl}$ solution of $\mathrm{pH} 10.5$ significantly increased the ion exchange capacity of the mineral, especially with a smaller excess of the regenerating agent.

Funding: The research was carried out as part of the research work no. WZ/WB-iIŚ/2/2021 at the Bialystok University of Technology and subsidized by the Minister of Education and Science.

Institutional Review Board Statement: Not applicable.

Informed Consent Statement: Not applicable.

Data Availability Statement: The data presented in this study are available on request from the corresponding author.

Conflicts of Interest: The authors declare no conflict of interest. The funders had no role in the design of the study; in the collection, analyses, or interpretation of data; in the writing of the manuscript, or in the decision to publish the results.

\section{References}

1. Xue, R.; Donovan, A.; Zhang, H.; Ma, Y.; Adams, C.; Yang, J.; Hua, B.; Inniss, E.; Eichholz, T.; Shi, H. Simultaneous removal of ammonia and $\mathrm{N}$-nitrosamine precursors from high ammonia water by zeolite and powdered activated carbon. J. Environ. Sci. 2018, 64, 82-91. [CrossRef]

2. Wang, S.; Peng, Y. Natural zeolites as effective adsorbents in water and wastewater treatment. Chem. Eng. J. 2010, 156, 11-24. [CrossRef]

3. Liu, Z.; Xu, B.; Lin, Y.; Zhang, T.; Ye, T.; Hu, C.; Lu, Y.; Cao, T.; Tang, Y.; Gao, N. A Mechanistic study on chlorine/nitrogen transformation and disinfection by-product generation in a UV-activated mixed chlorine/chloramines system. Water Res. 2020, 184, 116116. [CrossRef] [PubMed]

4. Millar, G.J.; Winnett, A.; Thompson, T.; Couperthwaite, S.J. Equilibrium studies of ammonium exchange with Australian natural zeolites. J. Water Process. Eng. 2016, 9, 47-57. [CrossRef]

5. Malovanyy, A.; Sakalova, H.; Yatchyshyn, Y.; Plaza, E.; Malovanyy, M. Concentration of ammonium from municipal wastewater using ion exchange process. Desalination 2011, 329, 93-102. [CrossRef]

6. Papciak, D.; Kaleta, J.; Puszkarewicz, A. Ammonium nitrogen removal from underground waters in the two-stage biofiltration process on the chalcedonite beds. Rocznik Ochrona Środowiska 2013, 15, 1352-1366.

7. Sprynskyy, M.; Lebedynets, M.; Terzyk, A.P.; Kowalczyk, P.; Namieśnik, J.; Buszewski, B. Ammonium sorption from aqueous solutions by the natural zeolite Transcarpathian clinoptilolite studied under dynamic conditions. J. Colloid Interface Sci. 2005, 284, 408-415. [CrossRef] [PubMed]

8. Zabochnicka-Świątek, M.; Malińska, K. Removal of ammonia by clinoptilolite. Glob. Nest J. 2010, 12, $256-261$.

9. Reeve, P.J.; Fallowfield, H.J. Natural and surfactant modified zeolites: A review of their applications for water remediation with a focus on surfactantdesorption and toxicity towards microorganisms. J. Environ. Manag. 2018, 205, 253-261. [CrossRef] [PubMed]

10. Huang, J.; Kankanamge, N.R.; Chow, C.; Welsh, D.T.; Li, T.; Teasdale, P.R. Removing ammonium from water and wastewater using cost-effective adsorbents: A review. J. Environ. Sci. 2018, 63, 174-197. [CrossRef]

11. Englert, A.H.; Rubio, J. Characterization and environmental application of a Chilean natural zeolite. Int. J. Miner. Process. 2005, 75, 21-29. [CrossRef]

12. Jaweda, A.; Saxenab, V.; Pandey, L.M. Engineered nanomaterials and their surface functionalization for the removal of heavy metals: A review. J. Water Process. Eng. 2020, 33, 101009. [CrossRef]

13. Derkowski, A.; Franus, W.; Waniak-Nowicka, H.; Czímerová, A. Textural properties vs. CEC and EGME retention of Na-X zeolite prepared from fly ash et room temperature. Int. J. Miner. Process. 2007, 82, 57-68. [CrossRef] 
14. Inglezakis, V.J.; Stylianou, M.A.; Loizidou, M.; Zorpas, A.A. Experimental studies and modeling of clinoptilolite and vermiculite fixed beds for $\mathrm{Mn}^{2+}, \mathrm{Zn}^{2+}$, and $\mathrm{Cr}^{3+}$ removal. Desalin. Water Treat. 2016, 57, 11610-11622. [CrossRef]

15. Kim, J.; Lee, J.; Choi, S.; Zhu, Q.; Lee, S. Nitrification of low concentration ammonia nitrogen using zeolite biological aerated filter (ZBAF). Environ. Eng. Res. 2020, 25, 554-560. [CrossRef]

16. Wua, Y.; Changc, C.C.; Guanc, C.Y.; Changc, C.C.; Lia, J.W.; Changc, C.Y.; Yu, C.P. Enhanced removal of ammonium from the aqueous solution using a high gravity rotating packed bed loaded with clinoptilolite. Sep. Purif. Technol. 2019, 221, 378-384. [CrossRef]

17. Park, S.J.; Lee, H.S.; Yoon, T.I. The evaluation of enhanced nitrification by immobilized biofilm on a clinoptilolite carrier. Bioresour. Technol. 2002, 82, 183-189. [CrossRef]

18. Weatherley, L.R.; Miladinovic, N.D. Comparison of the ion exchange uptake of ammonium ion onto New Zeland clinoptilolite and mordenite. Water Res. 2004, 38, 4305-4312. [CrossRef]

19. Balci, S.; Dinçel, Y. Ammonium ion adsorption with sepiolite: Use of transient uptake method. Chem. Eng. Process. Process Intensif. 2002, 41, 79-85. [CrossRef]

20. Sarioglu, M. Removal of ammonium from municipal wastewater using natural Turkish (Dogantepe) zeolite. Sep. Purif. Technol. 2005, 41, 1-11. [CrossRef]

21. Sprynskyy, M.; Lebedynets, M.; Zbytniewski, R.; Namieśnik, J.; Buszewski, B. Ammonium removal from aqueous solution by natural zeolite, Transcarpathian mordenite, kinetics, equilibrium and column tests. Sep. Purif. Technol. 2005, 46, 155-160. [CrossRef]

22. Rozic, M.; Cerjan-Stefanovic, S.; Kurajica, S.; Vancina, V.; Hodzic, E. Ammonical nitrogen removal from water treatment with clays and zeolites. Water Res. 2000, 34, 3675-3681. [CrossRef]

23. Sprynskyy, M.; Buszewski, B.; Terzyk, A.P.; Namiesnik, J. Study of the selec-tion mechanism of heavy metal $\left(\mathrm{Pb}^{2+}, \mathrm{Cu}^{2+}, \mathrm{Ni}^{2+}\right.$, and $\mathrm{Cd}^{2+}$ ) adsorption on clinoptilolite. J. Colloid Interface Sci. 2006, 304, 21-28. [CrossRef]

24. Huang, S.; Feng, J.; Yu, J.; Wang, Y.; Liu, J.; Chi, R.; Hou, H. Adsorption and desorption performances of ammonium on the weathered crust elution-deposited rare earth ore. Colloids Surf. A Physicochem. Eng. Asp. 2021, 613, 126139. [CrossRef]

25. Kamyab, S.M.; Williams, C.D. Pure zeolite LTJ synthesis from kaolinite under hydrothermal conditions and its ammonium removal efficiency. Microporous Mesoporous Mater. 2021, 318, 111006. [CrossRef]

26. Mahata, B.K.; Chung, K.-L.; Chang, S.-M. Removal of ammonium nitrogen $\left(\mathrm{NH}_{4}{ }^{+}-\mathrm{N}\right)$ by Cu-loaded amino-functionalized adsorbents. Chem. Eng. J. 2021, 411, 128589. [CrossRef]

27. Lutynski, M.; Sakiewicz, P.; Lutynska, S. Characterization of diatomaceous earth and halloysite resources of Poland. Minerals 2019, 9, 670. [CrossRef]

28. Kłapyta, Z.; Żabiński, W. Mineral Sorbents of Poland; AGH Press: Cracow, Poland, 2008. (In Polish)

29. Dobrzański, L.A.; Tomiczek, B.; Pawlyta, M.; Król, M. Aluminium AlMg1SiCu matrix composite materials reinforced with halloysite particles. Arch. Metall. Mater. 2014, 59, 335-338. [CrossRef]

30. Nadziakiewicza, M.; Kehoe, S.; Micek, P. Physico-chemical properties of clay minerals and their use as a health promoting feed additive. Animals 2019, 9, 714. [CrossRef]

31. Sakiewicz, P.; Nowosielski, R.; Pilarczyk, W.; Gołombek, K.; Lutyński, M. Selected properties of the halloysite as a component of Geosynthetic Clay Liners (GCL). J. Achiev. Mater. Manuf. Eng. 2011, 48, 177-191.

32. Sakiewicz, P.; Lutynski, M.; Sołtys, J.; Pytlinski, A. Purification of halloysite by magnetic separation. Physicochem. Probl. Miner. Process. 2016, 52, 991-1001.

33. Mrówka, M.; Szymiczek, M.; Machoczek, T.; Pawlyta, M. Influence of the Halloysite Nanotube(HNT) addition on selectedmechanical and biological properties of thermoplastic polyurethane. Materials 2021, 14, 3625. [CrossRef]

34. Keeling, J.L. The Mineralogy, Geology and Occurrences of Halloysite; Apple Academic Press: Oakville, ON, Canada, 2015.

35. Du, Q.; Liu, S.; Cao, Z.; Wang, Y. Ammonia removal from aqueous solution using natural Chinese clinoptilolite. Sep. Purif. Technol. 2005, 44, 229-234. [CrossRef]

36. Widiastuti, N.; Wu, H.; Ang, H.M.; Zhang, D. Removal of ammonium from greywater using natural zeolite. Desalination 2011, 277, 15-23. [CrossRef]

37. APHA. Standard Method for the Examination of Water and Wastewater, 21st ed.; American Public Health Association: Washington, DC, USA, 2005.

38. Dimova, G.; Mihailov, G.; Tzankov, T. Combined filter for ammonia removal—Part I: Minimal zeolite contact time and requirements for desorption. Water Sci. Technol. 1999, 39, 123-129. [CrossRef]

39. Franus, W.; Wdowin, M. Removal of ammonium ions by selected natural and synthetic zeolites. Miner. Resour. Manag. 2010, 26, 133-148.

40. Mazloomi, F.; Jalali, M. Ammonium removal from aqueous solutions by natural Iranian zeolite in the presence of organic acids, cations and anions. J. Environ. Chem. Eng. 2016, 4, 240-249. [CrossRef]

41. Ding, Y.; Sartaj, M. Optimization of ammonia removal by ion-exchange resin using response surface methodology. Int. J. Environ. Sci. Technol. 2016, 13, 985-994. [CrossRef]

42. Hankins, N.P.; Pliankarom, S.; Hilal, N. An equilibrium ion-exchange study on the removal of NH4+ ion from aqueous effluent using clinoptilolite. Sep. Sci. Technol. 2004, 39, 3639-3663. [CrossRef] 
43. Karadag, D.; Koc, Y.; Turan, M.; Armagan, B. Removal of ammonium ion from aqueous solution using natural Turkish clinoptilolite. J. Hazard. Mater. 2006, 136, 604-609. [CrossRef] [PubMed]

44. Perry, R.H.; Green, D. Perry's Chemical Engineers' Handbook; McGraw-Hill, International Editions: New York, NY, USA, 1997.

45. Lin, L.; Lei, Z.; Wang, L.; Liu, X.; Zhang, Y.; Wan, C.; Lee, D.-J.; Tay, J.H. Adsorption mechanisms of high-levels of ammonium onto natural and NaCl-modified zeolites. Sep. Purif. Technol. 2013, 103, 15-20. [CrossRef]

46. Balci, S. Nature of ammonium ion adsorption by sepiolite: Analysis of equilibrium data with several isotherms. Water Res. 2004, 38, 1129-1138. [CrossRef] [PubMed]

47. Wang, Y.; Kmiya, Y.; Okuhara, T. Removal of low-concentration ammonia in water by ion-exchange using Na-mordenite. Water Res. 2007, 41, 269-276. [CrossRef] [PubMed]

48. Zamri, M.F.M.A.; Kamaruddin, M.A.; Yusoff, M.S.; Aziz, H.A.; Foo, K.Y. Semi-aerobic stabilized landfill leachate treatment by ion exchange resin: Isotherm and kinetic study. Appl. Water Sci. 2017, 7, 581-590. [CrossRef]

49. Zhang, L.; Zhang, H.; Guo, W.; Tian, Y. Sorption characteristics and mechanisms of ammonium by coal by-products: Slag, honeycomb-cinder and coal gangue. Int. J. Environ. Sci. Technol. 2013, 10, 1309-1318. [CrossRef] 